\title{
KARAKTERISTIK DAN LUARAN PREEKLAMPSI DI RSUP PROF. DR. R.D. KANDOU MANADO
}

\author{
${ }^{1}$ Wahyuni Silomba \\ 2John Wantania \\ ${ }^{2}$ Joice Kaeng
}

\author{
${ }^{1}$ Kandidat SKRIPSI Fakultas Kedokteran Universitas Sam Ratulangi Manado \\ ${ }^{2}$ Bagian Obstetri dan Ginekologi Fakultas Kedokteran Universitas Sam Ratulangi Manado \\ Email:paai_manado@yahoo.com
}

\begin{abstract}
Maternal mortality is still one of the world health problems. It was estimated that more than 536,000 women per year died due to labor. In 2007, Indonesia maternal mortality rate (MMR) was 248 per 100,000 live births, which was the highest among SoutheastAsia countries. The most frequent cause of maternal mortality is hypertension in pregnancy. The insidence of pre-eclampsia in Indonesia is approximately 3-10\% of all cases of pregnancies, which is 23.6 per 1,000 births. This study aimed to determine the characteristics and outcomes of pre-eclampsia in Prof. Dr. R.D Kandou General Hospital Manado. This was a retrospective descriptive study. Data were obtained from the medical records of pre-eclampsia patients from January 1 until December 31, 2011 at the Department of Obstetrics Gynecology Clinic. There were 328 patients admitted to the hospital with a diagnosis of pre-eclampsia or eclampsia. The data consisted of 121 patients with mild pre-eclampsia, 103 patients with severe pre-eclampsia, 86 patient with superimposed pre-eclampsia, and 18 patients with eclampsia. Maternal deaths were $11.1 \%$. Perinatal deaths in mild preeclampsia were $1.6 \%$; in severe preeclampsia $3.8 \%$; in super-imposed pre-eclampsia 3.5\%; and in eclampsia $11.1 \%$. Conclusion: The most frequent cases of pre-eclampsia were mild pre-ecxlampsia, followed by severe pre-eclampsia, super-imposed pre-eclampsia, and eclampsia respectively. Perinatal deaths were the highest in eclampsia cases.
\end{abstract}

Keywords: preeclampsia, superimposed, eclampsia, maternal death, perinatal death.

\begin{abstract}
Abstrak: Kematian ibu masih merupakan salah satu masalah kesehatan dunia. Diperkirakan lebih dari 536.000 ibu per tahunnya meninggal akibat persalinan.Di Indonesia Angka Kematian Ibu (AKI) tahun 2007 adalah 248 per 100.000 kelahiran hidup, yang tertinggi dibandingkan negara-negara di Asia Tenggara. Salah satu penyebab kematian ibu bersalin paling sering yaitu hipertensi dalam kehamilan. Angka kejadian preeklampsi di Indonesia sekitar $3-10 \%$ dari semua jumlah kehamilan yaitu 23,6 kasus per 1.000 kelahiran. Penelitian ini berttujuan untuk mengetahui karakteristik dan luaran preeklampsi (PE) di BLU RSUP Prof. Dr. R. D Kandou Manado.Penelitian ini bersifat retrospektif deskriptif dengan melihat data rekam medik pasien PE periode 1 Januari - 31 Desember 2011 di Bagian ObstetriGinekologi. Terdapat 328 pasien yang dirawat dengan diagnosis PE sampai eklampsi, terdiri dari 121 preeklampsi ringan (PER), 103 preeklampsi berat (PEB), 86 superimposed preeklampsi, dan 18 eklampsi. Kematian maternal sebesar $11,1 \%$. Kematian perinatal pada PER sebanyak 1,6\%, PEB sebesar 3,8\%, super-imposed PE sebesar 3,5\%; sedangkan eklampsi sebesar $11,1 \%$. Simpulan: Jenis preeklamsi yang tersering ialah PER, diikuti PEB, super-imposed preeklamsi, dan eklamsi. Kematian perinatal tertinggi pada kasus eklamsi.
\end{abstract}

Kata kunci : preeklampsi, superimposed, eklampsi, kematian maternal, kematian perinatal. 
Kematian ibu sampai saat ini masih merupakan salah satu masalah kesehatan dunia yang perlu mendapat perhatian. Tahun 2005 WHO memperkirakan lebih dari $536.000 \mathrm{ibu}$ per tahunnya meninggal akibat persalinan. Khusus di Indonesia Angka Kematian Ibu (AKI) berdasarkan data Depkes RI tahun 2007 adalah 248 per 100.000 kelahiran hidup. Dibandingkan dengan negara-negara di Asia Tenggara, angka ini adalah yang tertinggi. Depkes RI berupaya menurunkan angka ini menjadi 206 pada tahun 2009 dan 124 per 100.000 kelahiran hidup pada tahun 2015. Salah satu penyebab kematian ibu bersalin paling sering yaitu hipertensi dalam kehamilan selain perdarahan dan infeksi yaitu sekitar $14 \%$ dari seluruh penyebab kematian ibu melahirkan. Angka kejadian preeklampsi di Indonesia sekitar $3-10 \%$ dari semua jumlah kehamilan yaitu 23,6 kasus per 1.000 kelahiran. Di RSUP Prof. Dr. R. D Kandou Manado tahun 2002 - 2003 kejadian preeklampsi ringan 151 kasus $(3,16 \%)$, preeklampsi berat 172 kasus $(3,59 \%)$ dan eklampsi 15 kasus $(0,31 \%)$ dari 4779 persalinan. Hipertensi dalam kehamilan mewakili kumpulan gejala yang berhubungan dengan peningkatan tekanan darah selama kehamilan, proteinuria dan dalam beberapa kasus terjadi kejang. Ini berkaitan dengan vasospasme, lesi vaskular pada sistem organ multipel, peningkatan aktivasi trombosit dan aktivasi selanjutnya dari sistem koagulasi pada vaskularisasi mikro. Eklampsi merupakan suatu konsekuensi preeklampsi yang terdiri dari kejang pada tingkat sistem saraf pusat yang sering mengakibatkan penurunan kesadaran dan berdampak kematian.

\section{TUJUAN DAN MANFAAT}

Untuk mengetahui karakteristik dan luaran preeklampsi di BLU RSUP Prof. Dr. R. D. Kandou Manado. Manfaat penelitian diharapkan dapat digunakan sebagai bahan masukan data untuk bagian Obstetri Ginekologi di RSUP Prof. Dr. R. D Kandou Manado sebagai acuan penelitian lebih lanjut.

\section{METODE}

Penelitian ini bersifat retrospektif deskriptif dengan melihat data rekam medik pasien preeklampsi. Penelitian ini dilakukan 1 Januari sampai 31 Desember 2011. Penelitian dilakukan di Bagian Obstetri Ginekologi di BLU RSUP Prof . Dr. R. D Kandou Manado. Subjek penelitian adalah semua pasien yang di diagnosa preeklampsi yang dirawat di SMF Obstetri Ginekologi RSUP Prof. Dr. R. D Kandou periode 2011.

\section{HASIL}

Tabel 1. Distribusi penderita preeklampsi berdasarkan umur.

\begin{tabular}{ccccc}
\hline \multirow{2}{*}{$\begin{array}{c}\text { Umur } \\
\text { ibu }\end{array}$} & PER & PEB & $\begin{array}{c}\text { Superimposed } \\
\text { PE }\end{array}$ & Eklampsi \\
\cline { 2 - 5 } & $\begin{array}{c}\text { Jumlah } \\
(\%)\end{array}$ & Jumlah (\%) & Jumlah (\%) & Jumlah (\%) \\
\hline$<20$ & $35(28,9)$ & $12(11,7)$ & - & $1(5,6)$ \\
$21-35$ & $72(59,5)$ & $55(53,4)$ & $30(34,9)$ & $10(55,5)$ \\
$>35$ & $14(11,6)$ & $36(34,9)$ & $56(65,1)$ & $8(44,4)$ \\
\hline & $\mathbf{1 2 1}(\mathbf{1 0 0})$ & $\mathbf{1 0 3 ( 1 0 0 )}$ & $\mathbf{8 6 ( 1 0 0 )}$ & $\mathbf{1 8 ( 1 0 0 )}$ \\
\hline
\end{tabular}


78 Jurnal e-Biomedik (eBM), Volume 1, Nomor 1, Maret 2013. hlm. 76-80

Tabel 2. Distribusi penderita preeklampsi berdasarkan pekerjaan.

\begin{tabular}{ccccc}
\hline Pekerjaan & PER & PEB & $\begin{array}{c}\text { Superimposed } \\
\text { PE }\end{array}$ & Eklampsi \\
\cline { 2 - 5 } & Jumlah (\%) & Jumlah (\%) & Jumlah (\%) & Jumlah (\%) \\
\hline IRT & $67(55,3)$ & $54(52,4)$ & $32(37,2)$ & $9(50)$ \\
PNS & $12(9,9)$ & $9(8,7)$ & $14(16,3)$ & $1(5,6)$ \\
Swasta & $15(12,4)$ & $16(15,5)$ & $27(31,4)$ & $3(16,7)$ \\
Lain-lain & $9(7,4)$ & $22(21,4)$ & $13(15,1)$ & $5(27,7)$ \\
\hline Total & $\mathbf{1 2 1}(\mathbf{1 0 0})$ & $\mathbf{1 0 3 ( 1 0 0 )}$ & $\mathbf{8 6 ( 1 0 0 )}$ & $\mathbf{1 8 ( 1 0 0 )}$ \\
\hline
\end{tabular}

Tabel 3. Distribusi penderita preeklampsi berdasarkan umur kehamilan.

\begin{tabular}{|c|c|c|c|c|}
\hline Umur kehamilan & PER & PEB & $\begin{array}{c}\text { Superimposed } \\
\text { PE }\end{array}$ & Eklampsi \\
\hline & Jumlah (\%) & Jumlah (\%) & Jumlah (\%) & Jumlah (\%) \\
\hline$<37$ & $32(26,5)$ & $41(39,8)$ & $31(36,1)$ & $10(55,6)$ \\
\hline 37 - 42 minggu & $89(73,5)$ & $62(60,2)$ & $55(63,9)$ & $8(44,4)$ \\
\hline & $121(100)$ & $103(100)$ & $86(100)$ & $18(100)$ \\
\hline
\end{tabular}

Tabel 4. Distribusi penderita preeklampsi berdasarkan paritas

\begin{tabular}{ccccc}
\hline Paritas & PER & PEB & $\begin{array}{c}\text { Superimposed } \\
\text { PE }\end{array}$ & Eklampsi \\
& & & Jumlah $(\%)$ & Jumlah (\%) \\
\cline { 2 - 5 } & Jumlah (\%) & Jumlah (\%) & $2(2,3)$ & $2(11,1)$ \\
Po & $48(39,7)$ & $47(45,6)$ & $13(15,1)$ & $7(38,9)$ \\
P1 & $32(26,4)$ & $31(30,1)$ & $45(52,3)$ & $8(44,4)$ \\
P2 & $28(23,2)$ & $8(7,8)$ & $23(26,8)$ & $1(5,6)$ \\
P3 & $9(7,4)$ & $12(11,6)$ & $3(3,5)$ & - \\
P4 & $4(3,3)$ & $5(4,9)$ & $\mathbf{1 0 6}(\mathbf{1 0 0})$ & $\mathbf{1 8 ( 1 0 0 )}$ \\
\hline Total & $\mathbf{1 2 1 ( 1 0 0 )}$ & $\mathbf{1 0 3 ( 1 0 0 )}$ & &
\end{tabular}

Tabel 5. Distribusi penderita preeklampsi berdasarkan jenis persalinan.

\begin{tabular}{|c|c|c|c|c|}
\hline \multirow[t]{2}{*}{ Jenis persalinan } & PER & PEB & $\begin{array}{c}\text { Superimposed } \\
\text { PE }\end{array}$ & Eklampsi \\
\hline & Jumlah (\%) & Jumlah (\%) & Jumlah (\%) & Jumlah (\%) \\
\hline Spontan lbk & $20(16,6)$ & $31(30,01)$ & $27(31,3)$ & $4(22,2)$ \\
\hline Spontan bracht & $1(0,8)$ & - & 1 & - \\
\hline Ekstraksi forceps & $3(2,5)$ & $1(1,0)$ & $(1,2)$ & - \\
\hline Ekstraksi vacum & $13(10,6)$ & $12(11,6)$ & $2(2,3)$ & $2(11,1)$ \\
\hline Sectio cesarea & $84(69,5)$ & $59(57,3)$ & $\begin{array}{c}3(3,6) \\
53(61,6) \\
\end{array}$ & $12(66,7)$ \\
\hline Total & $121(100)$ & $103(100)$ & $86(100)$ & $18(100)$ \\
\hline
\end{tabular}

Tabel 6. Distribusi penderita preeklampsi berdasarkan APGAR score bayi.

\begin{tabular}{|c|c|c|c|c|}
\hline \multirow[t]{2}{*}{ APGAR score } & PER & PEB & $\begin{array}{c}\text { Superimposed } \\
\text { PE }\end{array}$ & Eklampsi \\
\hline & Jumlah (\%) & Jumlah (\%) & Jumlah (\%) & Jumlah (\%) \\
\hline $1-3$ & $2(1,6)$ & $2(1,9)$ & $4(4,7)$ & $4(22,2)$ \\
\hline $4-6$ & $38^{*}(30,1)$ & $26^{*}(24,8)$ & $17(19,8)$ & $4(22,2)$ \\
\hline $7-10$ & $86^{*}(68,3)$ & $78(74,3)$ & $65(75,5)$ & $10(55,6)$ \\
\hline Total & $126(100)$ & $105(100)$ & $86(100)$ & $18(100)$ \\
\hline
\end{tabular}


Tabel 7. Distribusi penderita preeklampsi berdasarkan berat badan lahir bayi.

\begin{tabular}{ccccc}
\hline $\begin{array}{c}\text { Berat Lahir Bayi } \\
\text { (gr) }\end{array}$ & PER & PEB & $\begin{array}{c}\text { Superimposed } \\
\text { PE }\end{array}$ & Eklampsi \\
\cline { 2 - 5 } & Jumlah (\%) & Jumlah (\%) & Jumlah (\%) & Jumlah (\%) \\
\hline$<2500$ & $34(27)$ & $30(28,6)$ & $10(11,6)$ & $8(44,4)$ \\
$\geq 2500$ & $92(73)$ & $75(71,4)$ & $76(88,4)$ & $10(55,6)$ \\
\hline Total & $\mathbf{1 2 6 ( 1 0 0 )}$ & $\mathbf{1 0 5 ( 1 0 0 )}$ & $\mathbf{8 6 ( 1 0 0 )}$ & $\mathbf{1 8 ( 1 0 0 )}$ \\
\hline
\end{tabular}

Tabel 8. Distribusi penderita preeklampsi-eklampsi berdasarkan kematian maternal.

\begin{tabular}{ccccc}
\hline \multirow{2}{*}{$\begin{array}{c}\text { Kematian } \\
\text { maternal }\end{array}$} & PER & PEB & $\begin{array}{c}\text { Superimposed } \\
\text { PE }\end{array}$ & Eklampsi \\
\cline { 2 - 5 } & Jumlah (\%) & Jumlah (\%) & Jumlah (\%) & Jumlah (\%) \\
\hline Antepartum & - & - & - & - \\
Postpartum & - & - & - & $2(11,1)$ \\
\hline Total penderita & $\mathbf{1 2 1}$ & $\mathbf{1 0 3}$ & $\mathbf{8 6}$ & $\mathbf{1 8}$ \\
\hline
\end{tabular}

Tabel 9. Distribusi penderita preeklampsi-eklampsi berdasarkan kematian perinatal.

\begin{tabular}{ccccc}
\hline Kematian perinatal & PER & PEB & $\begin{array}{c}\text { Superimposed } \\
\text { PE }\end{array}$ & Eklampsi \\
\cline { 2 - 5 } & $\begin{array}{c}\text { Jumlah } \\
(\%)\end{array}$ & $\begin{array}{c}\text { Jumlah } \\
(\%)\end{array}$ & Jumlah (\%) & Jumlah (\%) \\
\hline Kematian neonatal dini & - & $1(0,9)$ & $1(1,2)$ & $1(5,5)$ \\
Lahir mati & $2(1,6)$ & $4(3,8)$ & $3(3,5)$ & $2(11,1)$ \\
\hline Total penderita & $\mathbf{1 2 6}$ & $\mathbf{1 0 5}$ & $\mathbf{8 6}$ & $\mathbf{1 8}$ \\
\hline
\end{tabular}

\section{BAHASAN}

Penelitian yang dilakukan melalui data rekam medik di poliklinik Obstetri Ginekologi periode 2011, tercatat 328 pasien yang dirawat dengan diagnosis preeklampsi sampai eklampsi. Data tersebut terdiri dari 121 penderita preeklampsi ringan, 103 penderita preeklampsi berat, superimposed preeklampsi sebanyak 86 penderita, serta eklampsi 18 penderita. Bila dibandingkan dengan kasus preeklampsi periode tahun 2002-2003 dimana angka kejadian preeklampsi diperoleh 338 kasus. Preeklampsi ringan 151 kasus, preeklampsi berat 172 kasus, dan eklampsi 15 kasus. Hal ini menunjukkan bahwa kasus preeklampsi dan eklampsi masih tetap banyak sehingga memerlukan penangananpenanganan yang komprehensif sehingga efek yang ditimbulkan baik terhadap ibu maupun bayi dapat diminimalisasi sehingga kualitas kesehatan ibu dan anak pasca kelahiran semakin membaik.

\section{SIMPULAN}

Berdasarkan hasil penelitian yang dilakukan secara retrospektif mengenai preeklampsi ringan, preeklampsi berat, superimposed preeklampsi dan eklampsi di BLU RSUP Prof. Dr. R. D Kandou Manado, dapat di tarik kesimpulan:

Karakteristik:

1. Umur terbanyak PER, PEB dan eklampsi 21-35 tahun; superiomposed PE $>35$ tahun.

2. Terbanyak Ibu rumah tangga.

3. Umur kehamilan preeklampsi ringan, berat, superimposed preeklampsi pada 37-42 minggu; sedangkan eklampsi paling banyak pada umur $<37$ minggu.

4. Paritas PER dan PEB, paritas 0; superimposed PE pada paritas 2; eklampsi pada paritas 2 .

5. Jenis persalinan preeklampsi ringan, preeklampsi berat serta superimposed preeklampsi paling banyak persalinan spontan lbk (letak belakang kepala); sedangkan eklampsi, sectio cesarea. 
80 Jurnal e-Biomedik (eBM), Volume 1, Nomor 1, Maret 2013. hlm. 76-80

Luaran:

6. APGAR Score: PER - eklampsi sebesar 7-10.

7. Berat lahir: PER, PEB,superimposed PE, eklampsi, $\geq 2500$ gr.

8. Kematian maternal sebesar $11,1 \%$.

9. Kematian perinatal pada PER sebanyak $1,6 \%$, PEB sebesar 3,8 \%, superimposed PE sebesar 3,5\%; sedangkan eklampsi sebesar $11,1 \%$.

\section{DAFTAR PUSTAKA}

1. Benson R, Pernoll M. Preklamsia. Obstetri dan Ginekologi. Jakarta: EGC, 2000.

2. Menkes. penurunan angka kematian ibu dan bayi jadi program priorétas tahun 2049 . Portal Akademik Universitas Gadjah Mada [homepage on the Internet]. Nodate [cited 2009 May 25]. Available from: webugm@ugm.ac.id.

3. Wenas J. Luaran kehamilan preeklamsia dan eklamsia di RSU Prof Dr Kandou Manado 2002-2003 [SKRIPSI]. Manado: Fakultas Kedokteran Universitas Sam Ratulangi; 2005. 